\title{
Role of the Wife in the Jewish Marriage in Old Testament Scripture, in Jewish Law, and in Rabbinic Literature
}

Kotel DaDon ${ }^{1}$

Faculty of Humanities and Social Sciences, University of Zagreb

kdadon@gmail.com

UDK:2-45; 2-555;26-4

Original scientific paper

DOI: https://doi.org/10.32862/k.12.2.2

\section{Summary}

The article is divided into three main sections: the first section analyzes the wife's role in the Jewish marriage, as well as various questions which are inseparable from her status in Judaism, such as social life, equality, and polygamy. The second section deals with the institution of marriage in Judaism, the very wedding ceremony, and various practical questions which may arise during the wedding and later. These include issues such as the ketubah and divorce. In the last section of this article, the author seeks to present the Judaistic stance toward violence against women, especially towards beating up and raping, and he ends with the Judaistic view on how we should treat our wives. The author analyzes the aforementioned topics from the Old Testament Scripture, the Jewish law, and the Rabbinic literature from the days of Talmud until today. The author breaks down these questions based on a series of sources from the Rabbinic literature, from the days of Talmud, through the Middle Ages, all the way to the modern Rabbis, and the literature which has been translated into Croatian for the first time. The texts have been translated from Hebrew and Aramaic by the author himself.

Key words: wife, marriage, Judaism, Talmud, Rabbi, Torah.

1 Doc. dr. sc. Kotel DaDon, Faculty of Humanities and Social Sciences, University of Zagreb; chief Rabbi in the Jewish Religious Congregation "Beth Israel” in Croatia. 


\section{Introduction}

In order to understand the Jewish stance on the position of women, one needs to delve deeper into the Jewish teaching, primarily into the way Judaism observes men and women, their rights and obligations, whose goal it is to create Jewish families. The position of women in Judaism is misunderstood by those who do not know Judaism closely. The reason for the incorrect understanding usually lies in the attempts to understand Jewish terms or customs by using terms or cultural references from the Western culture.

The position of families in the Western world is declining. This is primarily evident from a high percentage of divorces and single-parent families, an increase in the number of rapes and violence in the family, and sexual deviations. The secular society, which talks about equality, has turned the woman into a sex object and a symbol of seduction. Women are not shown in the Parliament, or in important and public positions as per her position in society; instead, the woman's image is used as a means of gaining economic profit through commercials, movies, and other means of communications. The woman is being abused as merchandise. Women suffer sexual abuse in their work places or where they serve in the army. This topic requires deeper examination in order to preserve the value of the family.

Judaism teaches that man and woman are different, both mentally and physically, and that each of them have their duties and tasks which fit them. This difference does not imply a difference in position or inequality. It is known today that men and women differ in their brain structures and in the way their brains operate. The difference between the sexes is a functional one, and not one pertaining to status.

\section{The Woman and Social Life}

Some have been absolved from many mitzvahs. ${ }^{2}$ Rabbi Samson Rafael Hirsch ${ }^{3}$

2 Mitzvah - (Hebr. מצוה - commandment; plural - mitzvot) is a legal norm in the Jewish law system. The mitzvahs which were derived from the Torah are called מדאוריתא (mideorajta) in Aramaic, while the mitzvahs which have been introduced by the Rabbis are called מדרבנד (miderabanan) in Aramaic.

3 Hirsch, Samson Rafael (Hebr.: Rabbi Shimshon Raphael Hirsch, in short: Rashar Hirsch) (1808-1888) - Leader of German Orthodox Jews in the $19^{\text {th }}$ century; regional Rabbi (Landesrabbiner) in Oldenburg and in Moravia. His most important rabbinate was in Frankfurt am Main, in the congregation, Adat Jeshurun. There, his thoughts have developed as neo-orthodox within orthodox Judaism. He introduced external changes into worship, such as choir singing with a conductor, and sermons in German. He is one of those who introduced changes 
explains the reason for this in his commentary on the Torah:

"because the purpose of the mitzvahs is to elevate man's spiritual level, and the woman was born with a spiritual advantage which doesn't require her to perform all the mitzvahs. She is also absolved from the mitzvahs in order to stop her from having too much burden on herself, because she is the one doing most of the housework. She is therefore absolved from teaching the Torah, but she is allowed to teach it if she so desires, while man is obligated to do so."

Mitzvahs have to be fulfilled by all women from the age of bat mitzvah ${ }^{5}$ and men from the age of bar mitzvah. ${ }^{6}$ Women are free from מצוות שהזמן גרמן, i.e., the commandments which are "determined by time" (BT 1961, kiddushin 35a; translated from Aramaic by K.D.), i.e. those which are done only at certain times, ${ }^{7}$ unless there is a special reason for the obligation. ${ }^{8}$

The duties and responsibilities of the woman are tied to everything that is related to the home's internal affairs: child-rearing and everything to do with the home, while the task and the responsibility of the man lies outside, in the affairs out of the home (BT 1961, Bava mecia 29b). According to Judaism, the home is more important than the life outside of it, which is opposite from the modern secular outlook, according to which the life outside of the home can be more important. When the husband goes to work, it is a necessity and an asset fo achieving a goal, i.e., the home. Working outside the house is the husband's obligation and the wife's right, according to financial needs. When the husband and wife see themselves as partners who strive for the same goal - raising a Jewish family each

into the Jewish School teaching program. He introduced general subjects into the school he founded in Frankfurt to provide comprehensive general education of Rabbis. His motto was: "The Torah is maximalized in partnership with worldly involvement." (Sayings of the Fathers, $2: 2$ ). He is the author of Torah commentaries and a book about symbolism and philosophy in Judaism.

4 Hirsh, Rabbi Shimshon Raphael, translation from German into Hebrew by: Rabbi Mordechai Breuer, Mossad Yitzhaq Breuer, Jerusalem, 1989 Lev 23:43; translated from Hebrew by K.D.; see DaDon 2009, 335.

5 bar mitzvah - Hebr. literally: son of the Law; adult age for boys; it comes into effect when the boy turns 13 years and a day, and from that time he is obligated to fulfill the mitzvahs: he puts on his tefillin, he is counted into the minyan and is called to the Torah, and he enjoys the fullfledged religious position (except in the case of being deaf and mute or mentally challenged); see DaDon 2009, 434-436.

6 bat mitzvah - Hebr. literally: daughter of the Law; adult age for girls; it comes into effect when the girl turns 12 years and a day; from that time she is obligated to fulfill mitzvahs like a grownup woman. See DaDon 2009, 434-436.

7 Such as sitting in the sukkah.

8 Eg., the mitzvah of Purim, since women had played a key role in the Purim miracle through Queen Esther. 
of them embraces their own tasks with all their might and they view their part as an asset. If, however, each of them sees their career as the most important thing, this can lead to marital crises, because neither of them wishes to give up on their career, or they disagree due to the feeling of competition in business success, which is expressed in the amounts of money they are making. This causes frustration for many married couples.

In Judaism, the wife is free from social obligations. The purpose of this is defending and guarding her own uniqueness and gentleness. A woman cannot testify in court, not because she is despised or not trusted; it is just like with a king, who may not testify because it is not fitting for him to be interrogated. In Judaism, witnessing in court is not just a right but an obligation. The Rabbis wanted to prevent women from getting into difficult positions during questioning and witnessing, thus preventing indecency. This only applies to cases which require two witnesses, because it is a public matter then; however, in cases when one witness is sufficient, the woman's testimony is accepted. The woman does not serve as judge because that is a public office, and she has been delivered from it. A judge's job requires him to study the Torah devoutly and this is something that women have been freed from as well (MT 1974, Hilhot talmud Tora 1,13; SA 1992, Jore dea 246,6). There have been exceptions in the past, such as Deborah the prophetess (see Judges 5), who was a special person in her time and place. The woman cannot serve as queen and have authority, because that is a hard and burdensome public service which does not fit her gentle and noble character and nature because, "The King's daughter is all glorious within" (Ps 45:13). ${ }^{9}$ The woman is also freed from going to war because that is a public obligation. The woman must pray once a day, but she's free from praying in the Minyan, ${ }^{10}$ because that is a public event which occurs three times a day. However, the situation has changed in today's modern world and religious women have taken a very active role in social life where they are involved in all kinds of professions from doctors, lawyers, all the way to university professors, and so on.

\section{Equality}

True equality stems from a starting point which acknowledges the natural differences between men and women in their features, temperaments, and characters. Stubborn, dogmatic, and blind equalization without considering physical

9 Author's own translation from Hebr. K.D.; Bible translations, if not otherwise stated, Sveto pismo Staroga i Novoga zavjeta, Jure Kaštelan - Bonaventura Duda (editor in chief), Zagreb, 2008. Where this translation uses the Tetragrammaton, the author replaced it with the words eternal or Lord, because it's not allowed to use God's name JHVH in Judaism.

10 minyan - ten men older than 13; a quorum required for certain prayers, such as the Kaddish. 
and mental differences is decidedly indefensible and impossible. The equality that is being brandished by the leaders of liberal society of the $21^{\text {st }}$ century is not factual. A study performed in Israel ${ }^{11}$ has shown that in the Israeli kibbutzes, ${ }^{12}$ which are undoubtedly man's greatest attempt in this area, after they were founded the physical duties have been equally divided between women and men. Women have not been entrusted with caring for children and yet the fifth generation in the kibbutzes is returning to family life.

The Torah and the Rabbis have acknowledged differences between men and women and they "translated" them into halachic ${ }^{13}$ details. Since there is a natural and true distinction between the sexes, there should also be differences in their roles and social duties. The wife's position in the Jewish family has, throughout its entire history, been more important than her position in any other culture within which the Jewish nation had lived.

\section{Judaism and Polygamy}

The Torah allows the man to be polygamous, while the woman is not allowed to marry multiple men at the same time (which is forbidden in most cultures). The reason for this is family, i.e., the need for the child's father to be known, which is very important in Judaism. When a woman has two husbands, it is not certain which one is the father. The second reason is the chastity of the Jewish woman, which is the foundation for a large part of traditional Jewish society.

However, since the beginning of the $11^{\text {th }}$ century, the Jews who lived in Christian countries have abstained from polygamous marriages. This was the consequence of regulations which forbade taking other wives. We ascribe this ban to one of the most important Rabbis at that time in Europe, Rabbenu Gershom Maor Hagol $^{14}$ (The Light of Diaspora). The background for this ban is controversial, as

11 Jediot aharonot, May 111988.

12 kibbutz - settlements in Israel, primarily agricultural, with common property and communal work, which were being established at the end of $19^{\text {th }}$ and beginning of $20^{\text {th }}$ century by Zionist returnees who were committed to the idea of the Jews returning to the land of Israel.

13 Halacha - 1. the legal part of Jewish religious literature; the name comes from the verb, halach (to go), because we're going, ie., following after Jewish law; 2. an individual stipulation from the halacha system.

14 Gershom, Rabbenu (Mainz /Magenca/ 965 - 1028) - son of Yehuda, also known as Maor hagola (Light of the Diaspora), which is a witness to the great respect of his generation, as well as the generations that followed, for him. He was the most renowned leader of Ashkenazi Jews at the time of their rise. He lived in France and in West Germany, he was a Rabbi and the leader of the Mainz yeshiva, the teacher of Rashi's teacher. His yeshiva was the main center for teaching the Torah for the Ashkenazim in Germany, in his time. Many of his students and the students of his students have written commentaries on the Talmud, and the best known among them is Rashi, who taught under Rabbi Jaakov ben Jakar and Rabbi Jichak ben Jehuda, both of them 
some believe that Christians were accusing Jews for condoning adultery, i.e., forbidden sexual relations, because Christians were only allowed to have monogamous marriages, while Jews were allowed to take another wife. Others, however, believe that the ban was given in order to empower the status of women.

Rabbenu Gershom is considered to be one of the greats among the Ashkenazi Rabbis, and his decision only affected his own area of jurisdiction. We know that the Sephardis (in Spain, Turkey, North Africa, Yemen, Greece) did not accept this ban and continued to take multiple wives.

Rabbi Yosef Karo, ${ }^{15}$ the author of Shulhan Aruh, a Sephardic book of Jewish Law, allowed taking multiple wives (SA 1992, Even Haezer 1,9-10), while Rabbi Moshe Isserles, Rema, ${ }^{16}$ Ashkenazi halachic authority, comments his words in this way, "In any case, in all these countries (in all Ashkenazi territories) the rule and custom (as made known by Rabbenu Gershom) still remains firm and everybody is forbidden from breaking this rule and taking two wives before he divorces one." Today, the ban prescribed by Rabbenu Gershom is accepted in all Jewish communities all over the world. ${ }^{17}$

In rare circumstances, the man is allowed to take a second wife with the consent of 100 Rabbis. For example, in a situation where the wife became mentally ill and the man is no longer able to live with her but is also unable to divorce her (because it is considered that a mentally ill person is unable to decide if they want to get a divorce). The wife, on the other hand, cannot receive such consent from

students of Rabbi Gershoma. He is ascribed authorship of piyuts (pious songs) and commentaries on several Talmudic tracts. He ordered the so-called Rabbi Gershom's herem (ban), which forbids men from taking multiple wives and from divorcing against the wife's will. This ban remains in Israel and the Diaspora to this day.

15 Karo, Rabbi Yosef (Spain 1488 -1575) - also known as Maran, which means "our teacher" in Aramaic, because his halachic codex, Shulhan aruh, has been accepted in all diaspora countries, and it still applies today. After the Jews were driven out of Spain in 1492, he moved to Portugal, then to Turkey, where he lived and taught for forty years. In 1535, he moved to Safed in Galilee, which was the spiritual and mystic center of Israel at the time. He became one of the leading people and he was in charge of a large yeshiva. Two of his most famous students were Rabbi Moshe Cordovero and Rabbi Moshe Alshih, renowned mystics from Safed.

16 Isserles, Moses (Rabbi Moshe Iserles; short: Rema) (Krakow, 1520 - Krakow, 1572) Son of Israel. The leading european Ashkenazi halachich authority of his day. Rabbi, main judge and the head of the Krakow yeshiva, from where he influenced Germany, Poland, and Northern Italy. An author of several books, most famous one of which is HaMapah, an addition to the Shulchan Aruh of Rabbi Yosefa Karoa, which includes Ashkenazi customs, and both communities were able to use the same book. He wrote a lot of responsas, he knew the Kabbalah, phylosophy, astronomy, history, and especially the Torah and the chalacha. As a young man, he was appointed judge and chairman of the Krakow yeshiva, and it was said of him, "from Moshea (Maimonides) to Moshea (Rem) there wasn't one such as Moshea (Rem).“

17 The Jews in Yemen take multiple wives even today. 
the Rabbis regardless of the situation and she is unable to remarry before getting a divorce from her previous husband.

\section{Establishing a Marriage in Judaism}

"Then the Lord God said, 'It is not good for the man to be alone; I will make him a helper suitable for him. So the Lord God caused a deep sleep to fall upon the man, and he slept; then He took one of his ribs and closed up the flesh at that place. The Lord God fashioned into a woman the rib which $\mathrm{He}$ had taken from the man, and brought her to the man. The man said, 'This is now bone of my bones, and flesh of my flesh; she shall be called Woman, because she was taken out of Man.' For this reason a man shall leave his father and his mother, and be joined to his wife; and they shall become one flesh" (Gen. 2:18; 21-24).

The most important private Jewish institution is marriage, which is also the foundation for honoring many of God's commandments. Judaism sees marriage as the only way for a man and a woman to be able to have a life together. God created man and woman as the idea form of life, "He created them male and female, and He blessed them and named them Man in the day when they were created" (Gen. 5:2). The Talmud explains that they are only called "man" when they are together, which denotes completeness (BT 1961, Yevamot, 63a). In another place, the Talmud says, "Any man living without a wife, lives without happiness, without blessings, without kindness" (BT 1961, Yevamot, 62b; translated from Aramaic by, K.D.).

Judaism advises all congregation members to get married and nobody is exempt from marriage so even religious leaders and scholars need to establish their own families.

The first mitzvah in the Torah is the procreation commandment, "God blessed them; and God said to them, 'Be fruitful and multiply, and fill the earth, and subdue it; and rule over the fish of the sea and over the birds of the sky and over every living thing that moves on the earth"' (Gen. 1:28).

This is how the Mishna ${ }^{18}$ explains this commandment, "The man will not refrain from performing from duty of procreation, unless he already has children [in terms of numbers]. Beth Shamai ruled: two male children, and Beth Hilel ruled: male and female, because the Scripture says, 'He created them male and

18 Mishna - repetition, teaching; 1. foundational oral Torah literature regarding Jewish law; it was edited by Rabbi Yehuda Hanasi (188) and it consists of six main sections (Shisha sidre Mishna); the largest and most important source of the halachah (Jewish law) from the tanaita times, the corpus of juris halacha; 2. each stipulation in the Mishna system (cf. DaDon 2009, 512). 
female"' (Gen 5:2) (BT 1961, Yevamot, 61b; translated from Aramaic by K.D.).

Scholars believe that this mitzvah is obligatory only for men, "It was man who was given the procreation commandment, but not the woman. Rabbi Johanan b. Beroka said, "It was said of both of them [Adam and Eve, i.e., man and woman], "God blessed them; and God said to them, 'Be fruitful and multiply"' (Gen 1:28) (BT 1961, Yevamot, 65b; translated from Aramaic by K.D.).

This commandment requires that everyone should have at least two children, a boy and a girl, and when this mitzvah cannot be fulfilled it can be taken as reason for divorce. In another place, we asked the question regarding artificial insemination in this context: when one uses the artificial insemination method, are they really honoring the Biblical commandment to "be fruitful and multiply" (see DaDon 2014, 75-76)?

Furthermore, an unmarried Rabbi is not allowed to perform the ministry of Rabbi. It should be noted there were some minority groups in the Jewish nation during the Second Temple period who have embraced celibacy, but most of the people did not accept such a stance. Besides, according to Jewish tradition, it is God Himself who takes part in finding a partner for each person (BT 1999, Moed Katan, 18b; See also MBR 68,4).

In the beginning of mankind, marriage was established when the partners first had sex, as is claimed by Maimonides (MT 1974, Hilhot ishut 80,1). It was a relationship with no commitment, ancient, a fruit of momentary passion. When the Torah was received, the commandment of marriage was given, as well as of its form and details. The first condition of marriage is that both partners must be Jewish (Deut. 7:3; see also BT 1961, kiddushin 68b; SA1992, Even haezer 16).

\section{Jewish Marriage in Ancient Times}

The Jewish wedding is divided into two steps: erusin (the engagements), or kiddushin (consecration), and nisuin (wedding). The name, kiddushin - consecration - talks about the essence of this institution. In Judaism, marriage is considered sacred; a relationship where one partner devotes themselves to another with the goal of establishing a Jewish home. It is a deep relationship, which includes the rights and obligations of both partners. This relationship is entered deliberately, with mutual respect and knowledge of the goal: and building another station for the Jewish people which will ensure the continuation of the Jewish people's historical task and eternal calling: to be an eternal nation. The ceremony of kiddushin is really when the man acquires the wife with her consent because the ceremony could not go on without it. This ceremony also requires the presence of two appropriate (kosher) witnesses, ${ }^{19}$ according to the Torah: "A single witness 
shall not rise up against a man on account of any iniquity or any sin which he has committed; on the evidence of two or three witnesses a matter shall be confirmed" (Deut. 19:15).

The Rabbis teach (Mishna in BT 1961, kiddushin 2a) that the kiddushin can be performed in one of three ways:

With the money or some other value given to the woman by the man, with the statement, "Behold, you are consecrated to me with this money (or, with this item of value)." This way of establishing marriage was taught by Rabbis based on the Torah: "If any man takes a wife" (Deut. 22:13). When the Torah talks about taking, it is always referring to buying for money, like Abraham said when he was buying the Machpelah cave, "I will give the price of the field, accept it from me" (Gen. 23:13).

With a deed given to the woman by the man, which states, "Behold, you are consecrated to me with the deed." The deed would be signed by witnesses. This kind of establishing marriage was taught by the Rabbis (BT 1961, kiddushin 2b) from the Torah, with the addition that the wife, after she is divorced, gets a divorce deed called "get," thus is also the establishment of marriage followed by issuing a deed.

With sexual intercourse between partners that has the purpose of establishing marriage. This way of establishing marriage was taught by the Rabbis from the Torah: When a man takes a wife and marries her (bě 'alah)... (Deut. 24:1). The word, בעלה ba 'alah (marries her) has been interpreted as, בא עליה 'aleha (came in to her), i.e., has sexual intercourse with her. It was necessary for the witnesses to see the couple entering the room together and close the door and the witnesses would then wait for as long as it took for the intercourse to take place. This kind of establishing marriage was forbidden by the Rabbis due to indecency, as well as the possibility that the purpose of the sexual intercourse was not to establish a marriage, but for momentary pleasure. It is known that ${ }^{20}$ has cursed

have met the conditions; eg., they may not be related to any of the involved parties, they have to honor God's commands, etc.

20 Aba Ariha, called Rav (175-247) - First of the amoraim and the last of the tannaim. He got his nickname (Hebr.: rav = Rabbi, teacher) due to his importance and the fact that he studied under Rabbies (Hebr.: $m y$ teacher). Taught in halacha and aggadah. Founder of university (yeshi$v a$ ) in Sura, Babylon. His work is the basis for creating the Babylonian Talmud. His statements would often be used as proverbs. He opposed seclusion and nazirism, saying, "In the world to come, man will have to give an account for all that his eye has seen, and he hasn't eaten." (JT, end of the kiddushin tract). Accepted as the ultimate authority for stipulations regarding the relationships between man and God, such as kashruth, regulations regarding ceremonial cleanliness, etc. He is ascribed authorship of certain prayers, such as Alenu leshabeach, a segment of the Hagaddah for the Pesach, the blessings of the Moon, blessings of the New Moon, and others. Also known as the student of Rabbi Shimon bar Yohai, the author of Zohar. 
(BT 1961, kiddushin 12b) the man who got married through sexual intercourse.

At the end of the first step towards marriage, sexual intercourse was forbidden with everyone, including the husband, and in ancient times the wife would go back to the family home up until nisuina, i.e., wedding under the Chuppah.

The ceremony of נישואין - nisuin - i.e., the Chuppah (canopy) ceremony, would be prepared for about a year, and it contained seven blessings and the giving of the ketubah (marriage deed), after which the wife goes to her husband's home, and she is only allowed to have sexual intercourse with her husband.

\section{The Jewish Marriage Today}

Today, all that is left of the erusin is the engagement custom. They have no legal power but are an expression of the partners' mutual agreement with their families regarding their intention to get married. In Ashkenazi communities, it is customary to create a "conditions document" (םיאנת רטש shetar tena'im), as a written agreement between the partners' parents, which contains details regarding the time of the wedding, cost-division, and other needs of the couple. This agreement is made between parents, because in older times it was the younger people who would get married, who had no money or other assets. The purpose of this agreement is to strengthen the bond and to secure a source of income for the couple. It is customary to then break a plate in remembrance of the destruction of the Temple, precisely at that happy moment. In Sephardic communities, it is customary to apply henna. During the ceremony, the newlyweds and their families wear traditional Sephardic clothes. All those present would dance in their honor. After that, the groom's mother would present the bride with all sorts of jewelry. At the end, the couple applies henna from a prepared dish on their hands, and then on everybody else's hands. Everything is accompanied with singing and dancing. The traces of henna remains on their hands for about a week, and the purpose of it is to be a distinguishing mark which will be a witness of the bond created between the newlyweds and their families before the community, and the bond's purpose was to get married. The wedding day and cost-splitting are usually arranged verbally.

Today, kiddushin and nisuin are prepared on the same day, and not like in Talmud days, when the partners would be separated for a time between the two ceremonies. It is Ashkenazi custom for the bride and the groom to fast on the wedding day, because for them that day is a sort of Yom Kippur, a day of re-examining; a day of transition into an important and significant day of their lives. That is why it is important for them to enter this day with prudence and sobriety. In the minhah, they pray the viduy, just like on the erev Yom Kippur. The reason for this fast also lies in the forgiveness of sins. The fast is to last throughout the wedding ceremony. 


\section{The Marriage Contract - Ketubah}

Today, the ceremony starts with the signing of ketubah. The groom signs it first and then the two witnesses. Ketubah כתובה is a document which lists the obligations of the husband and the rights of the wife. It was first created at the beginning of the second Temple by the members of the Great Assembly (Keneset hagedola). ${ }^{21}$ The purpose of the ketubah is to ensure the wife's rights in marriage, in case of the husband's death or divorce. In the ketubah, the husband is obligated to secure food and decent clothing for her and to retain sexual relations with her, as ordained by the Torah, "If he takes to himself another woman, he may not reduce her food, her clothing, or her conjugal rights" (Ex. 21:10). He is also obligated to provide for her medical treatments and for her funeral. The husband is obligated to ensure a payment of a certain amount of money in case of divorce or his death. For the moment when the wife is left without her husband, who is the bread-winner and provider of a firm economic foundation, the Rabbis have secured a quick way of support, so the woman would not be forced into an unpleasant situation of depending on others. The amount allotted to the previously unmarried woman is two times higher than the one allotted to the divorced or widowed woman, because the two of them have already received money from their previous husband's ketubahs. There's also mention of the dowry which the wife brought from her parental home and the groom adds the amount from the ketubah on top of it. This additional amount is one third of the dowry. The ketubah does not reveal the amounts which give the total; rather, a sum total is determined that is called, the sum total of ketubah סך כל הכתובה. The groom proclaims that he is voluntarily taking on this obligation and that he vouches for this amount with his movable and immovable assets that he has at his disposal and which he will have at his disposal from the wedding day and onward. The groom commits to giving her the ketubah amount during his life - if they are divorced - or after his death if she becomes a widow. In case of the ketubah, Shimon ben Shetah ${ }^{22}$ decided that

21 On the basis of Mishna and a BT tract 1961, Ketubot 110b there was discussion regarding the source of the ketubah law: did it come directly from the Torah or from a later, Rabbinic period. The debate was led between the wise men from Spain, under the leadership of Gaon from Babylon, and Rif (at the end, Ketubot), and Maimonides (Hilhot ishut 10,7-8), his son Rabbenu Avraham (in Responsa no. 82). All opinions state that the ketubah law comes from the Rabbinic authority, and it was so determined, just like halacha, by Rabbi Yosef Karo (SA 1992, Even haezer 66,6). The Ashkenazi wise men, though, led by Rabbenu Tam, outlined a completely opposing opinion (Tosafot, BT Ketubot 10a, section Amar rav Nahman) that it does come from the Torah. For details of the debate, see Responsa Jabia Omer by Rabbi Ovadiah Yosef, scr. 3., Even haezer ch. 12. This distinction is the cause for the difference between the Askhenazi ketubah and the Sephardic ketubah.

22 Shimon ben Shetah (turn of $2^{\text {nd }}$ to $1^{\text {st }}$ centuries BC) - President of the Sanhedrin until 3722 from the creation of the world, ie., 38 BC, at the time of King Alexander Jannaus, who was a 
all of the husband's assets, movable and immovable, would be taken as guarantee (BT 1999, Šabat 14b; cf. SA 1992, Even haezer 66,1) for the needs of paying out the ketubah in case of divorce or the husband's death. The text of the ketubah is in Aramaic, the spoken language of the people at the time it was written. The modern text comes from the Babylonian Jews from the times of gains.

\section{The Purpose of the Ketubah, Once and Today}

The ketubah was not only meant to be a list of the wife's rights, but it also had other important goals, such as deepening the economic security and preventing sudden divorces after a momentary crisis in a marriage (BT 1961, Ketubot 39b). According to Torah Law, it is only possible to get married with the woman's consent but the man can get a divorce without her consent. Although he does need a valid reason to get a divorce, he does not need his wife's consent. In situations where polygamy and divorce without the wives' consent are allowed, divorced women and widows were facing difficult economic problems. For example, when a man died and left several widows after him, a bitter struggle for the inheritance would begin. In such cases, force would usually win, and widows would remain lonely, disenfranchised, and desperate.

The ketubah helps the woman in two ways. First, it determines that the widow has the first right in inheriting the amount listed in the ketubah, before the other heirs divide the money among themselves. Second, in case of an argument or a crisis in marriage, if the wife would wave the ketubah, many husbands would think twice before deciding to get a divorce and would then give up on his intentions. If, however, the marriage would end in a divorce, the wife would receive a nice amount of money which would help her start up a new life.

Today, the ketubah lost its importance due to several other regulations that were made at a later date. The most famous one is Herem deRabbenu Gershom Maor hagola, through which Rabbenu Gershom forbade polygamy. Another regulation was put forth, which made it possible to secure food after the divorce and another newer regulation proposed that divorce requires the wife's consent. These regulations changed the conditions which had made the ketubah necessary. Today, there is no need to threaten the husband with the amount from the ketubah, because he cannot get divorced without her consent anyway, and she

Saducee. His sister was Queen Shlomtzion, the King's wife. He is known for opposing the Saducees, who were against the oral Torah, supported by the King, who he wasn't on good terms with because of it (BT Sanhedrin 19a). After the King's death, Queen Shlomtzion gave full support to her brother, who managed to abolish the Saducees and their influence, and to strengthen the position of the oral Torah in the nation. He issued several important regulations, like the one that children must attend school (JT Ketubot 8, near the end), as per the example of the school he founded in Jerusalem. 
does not need to be satisfied with the amount from the ketubah but can require other conditions to be met for her to give her consent, such as monthly support, paid housing expenses, and the like. There is also no rivalry between the widows today because there is no polygamy.

\section{Chuppah}

After signing the ketubah, the groom (hatan חתת), followed by the fathers of both newlyweds, goes to the bride (kala כלה), who sits between the two mothers. Once he reaches her, he covers her face with a veil which symbolizes Jewish chastity. The roots of this custom reach deep in Jewish history: before Rebeccah and Isaac got married, when Rebeccah first saw Isaac, "...Then she took her veil and covered herself" (Gen. 24:65). In the most exciting event in the young couple's life, the hatan is followed by two fathers, and the kala with both mothers. Judaism gives equal respect to both parents. From now on, hatan will have two fathers and kala will have two mothers. If the parents are deceased, it is customary to honor a related married couple. It is good that they are in their first marriage, which is tranquil, and that they have not been widowed or separated. The point of those who accompany them (שושבין shoshvin, plural: shoshvinim) is that the newlyweds would be like a king and queen on their wedding day, who are always followed as a way of honoring them. After the groom has covered the bride's face, he and the accompanying party start going towards the chuppah - the wedding canopy - together where he waits for his bride. Hatan is waiting for his kala, and not her for him, because that would be inappropriate. Kala walks towards the chuppah with her company and once she reaches it, she stands on the hatan's right.

The chuppah חופה is a piece of cloth that is stretched using poles like an eaves and the wedding is held underneath it. In Mishna and Talmud, chuppah is the name for the wedding ceremony (Mishna 1987, Avot 5,21; see also BT 1961, Ketubot 48b). Stretching of the chuppah symbolizes the building of a new home in the Jewish people. The chuppah is mentioned in the Pentateuch, “... Which is as a bridegroom coming out of his chamber (i.e., chuppah)" (Ps. 19:5) (Translated by K.D.). In the times of Mishna, the chuppah holders were made out of the branches of a cedar tree which was planted on the day of the newlywed's birth (BT 1961, Gitin 57a). The Sephardis stretch a tallit as chuppah over the heads of the newlyweds while the Ashkenazi stretch out a piece of cloth called, parochet. The Yemenites are holding onto Maimonides' words (MT 1974, Hilhot išut 10,1) and think that the chuppah is actually the moment when the couple are left in the room together so they do not stretch a canopy over the couple. The places for setting up the chuppah are also different. The Sephardis set up the chuppah in the synagogue, while the Ashkenazi set it up out in the open. With the Ashkenazi, it is customary that the kala, once she reaches the chuppah, would hold candles in 
her hands, walk around the hatan seven times, and stands on his right at the end. The fathers stand next to the groom and mothers stand next to the bride.

\section{The Wedding Ceremony}

The Rabbi who organizes the ceremony is the groom's emissary. He blesses the wine, and then utters the erusin blessing:

"Blessed are You, Lord our God, Master of the Universe, Who has sanctified us with His commandments, and commanded us regarding forbidden unions, and Who forbade betrothed women to us, and permitted to us those married to us by huppah and kiddushin. Praised are You, Lord, Who sanctifies His people Israel with huppah and kiddushin."

After the blessing, the hatan and kala drink the wine but they do not bless it because the Rabbi has already done so.

Today, it is customary during the wedding to use the prescribed "money" in the form of a ring which the groom gives to the bride. The smallest allowed value of the ring is called, perutah - פרוטה - pennyworth, which is a particle of silver with the volume of half a seed of barley. The Rabbies have decided that the ring must be gold and simple, with no decorations and precious stones, so as not to create differences between the rich and the poor and because even the most precious ring cannot meet the worth of a woman. It is important to note that, in Judaism, putting on the ring is not a wedding symbol; instead, it is the wedding, as it is the act of the kiddushin. That is why the groom must buy the ring with his own money, otherwise the wedding would be void. Before putting on the ring, hatan says to kala in the presence of two witnesses:

"Behold, by this ring you are consecrated to me as my wife according to the laws of Moses and Israel."

After this, he puts the ring on her right-hand finger. With this sentence, the groom provides purpose to the act of wedding and gives it legal power according to Jewish law, which means that it can only be dissolved within the Jewish law, i.e., at the Rabbinic court. The ring that the groom puts on his own hand, i.e., the one given to him by the bride, is a non-Jewish custom (which has been accepted by the Jews), since the man is the one consecrating the woman, not the other way around. That is why he puts the ring on his hand, or the wife does it for him, only at the end of the chuppah ceremony.

The Rabbi reads the ketubah, which was already written and signed before the wedding. After that, the hatan hands the ketubah to the kala with his right hand, and she takes it with her right hand.

After the groom has given the ketubah to the bride, the "Seven Blessings of Marriage" are prayed: 
"Blessed are You, Eternal One, Lord our God, Master of the Universe, Who has created the fruit from the vine."

"Blessed are You, Eternal One, Lord our God, Master of the Universe, Who has created everything for Your honor."

"Blessed are You, Eternal One, Lord our God, Master of the Universe, Creator of man.”

"Blessed are You, Eternal One, Lord our God, Master of the Universe, Who has created man in Your own image and arranged his home for ever and ever. Blessed are you, Eternal one, Creator of man".

"Rejoice and be glad, you who are left without sons, when the sons gather in you joyfully. Blessed are You, Eternal One, who brings joy to Zion with his sons."

"Make Your dear friends joyful with gladness, just as you brought joy to Your creation in the Garden of Eden. Blessed are You, Eternal One, who brings joy to the groom and the bride."

"Blessed are You, Eternal One, Lord our God, Master of the Universe, who has created joy and gladness, song, singing, shouts and friendship, love and fellowship, peace and comradery. Quickly, Eternal One, our God, may the hills of Judea and the streets of Jerusalem resound with the sounds of gladness and sounds of joy, the voice of the groom and the voice of the bride, the shouts of the grooms under their chuppahs and of the young men from their feasts. Blessed are You, Eternal One, who brings joy to the groom and the bride."

After reading the seven blessings, the newlyweds drink from the blessed wine again. Then the groom says the verse:

"If I forget you, O Jerusalem, may my right hand forget her skill.

May my tongue cling to the roof of my mouth if I do not remember you, if I do not exalt Jerusalem above my chief joy" (Ps. 137:5-6).

Then the groom smashes the glass by stepping on it with his right foot, which symbolizes the sorrow and pain because of the destruction of the Temple, which is the symbol of the Jewish home. We are reminded of the destruction of our home at the very climax of happiness, when we are building our own home, to remind ourselves that our home is still in ruins and most of the people live in the diaspora. The verses that the groom says before smashing the glass are the words of the oath of the Israelites who were exiled into Babylon after the destruction of the first Temple. It is an Ashkenazi custom that the witnesses would walk the couple to the room, where they will stay alone for the first time as husband and wife (jihud). On that occasion they will eat a light meal, because Ashkenazi custom requires that they would fast on that day. Sephardi newlyweds are left alone a little later, in the night after the wedding. 


\section{The Jewish Marriage - Various Views in Judaism}

The wedding ceremony here is as described by Orthodox Judaism and is accepted by most of Jewish public in Israel. However, many Jews around the world have different wedding ceremonies, according to the rules of the conservative and reformist movements.

According to the law enforced by the Chief Rabbinate of Israel, the Orthodox wedding ceremony is the only one considered valid for Jews in Israel. Besides, the institution of civil marriage does not exist in Israel although, in line with international law, the State of Israel does recognize marriages that were established in other countries according to reformist and conservative rituals and even civil marriages. The reason for this is the fact that the validity of the wedding ceremony is affirmed by the laws of the country where the wedding was held. Israeli citizens who wish to get married in a civil ceremony must do so in other countries.

In the reformist and sometimes even in the conservative ceremonies, the groom gives the ring to the bride and the bride gives the ring to the groom. Aside from this, the reformist movement insists that both the groom and the bride would be involved in forming the ritual so that the ceremony would reflect their own characters and the nature of the relationship between them. The couple are called to partake in forming the Ketubah text, and they can even select various versions of blessings and they can add readings.

\section{The Joy of Hatan and Kala}

It is an important commandment to make the groom and the bride happy on their wedding day. This commandment is so important that we can find debates in the Mishna and the Talmud on how they should be made happy. In one place in the Mishna the Rabbis discuss the issue of "how shall we dance in front of the bride?"(BT 1961, Ketubot 16b; translated from Aramaic by K.D.). It is amazing to see how personally the great Rabbis took to fulfilling the commandment of making the groom and bride happy:

"Rabbi Yehuda bar Eli waved a myrtle branch and danced before the bride, saying, Beautiful and pious bride... rav Shemuel bar rav Jichak danced with three myrtle branches... rav Aha danced while carrying the bride on his shoulders... there is also talk of King Agrippa dancing before the bride, and the Rabbis commended him" (BT 1961, Ketubot 16b; translated from Aramaic by K.D.).

\section{Seven Days, Seven Blessings}

At the end of the wedding dinner comes the uttering of the zimun, ${ }^{23}$ which

23 Zimun - a call to prayer - If the three have eaten together, they have to say the zimun, a call to prayer, before praying for dinner. 
keeps the memory of the wedding day event, followed by birkat hamazona, ${ }^{24}$ and then he says the blessing over the wine. At the second glass of wine, the guests utter the remaining six wedding blessings after which the wine from both glasses is mixed and poured back again into the glasses, one of which is drank by the groom and the other by the bride. A dinner is prepared in the honor of the newlyweds each night during the seven days of the wedding, where the words from the Torah are said and the seven blessings are repeated. These seven blessings are celebrated in a different place every night: in the bride's parental home, groom's parental home, homes of their brothers and sisters, and their friends.

\section{Shabbat Hatan and Shabbat Kala - the Groom's Shabbat and the Bride's Shabbat}

Shabbat hatan שבת חתן is a shabbat when the hatan climbs up to the Torah in the synagogue. According to Ashken custom, this shabbat comes before the wedding, while according to the Sephardi custom, this shabbat comes after the wedding because he is only called "hatan" - celebrant - after the wedding. On this shabbat, we honor the hatan by calling him to the Torah or to read the haftarah, which includes the reading of the Torah. A celebration is prepared in the synagogue in his honor, and songs are sung that are customary for the shabbat hatan. As he ascends towards the Torah, it is a favorite custom to throw desserts at him, which symbolizes the wishes of all present that the hatan's and his wife's life would be sweet. At the end of the prayer, it is customary to prepare a kiddush in hatan's honor in the synagogue. In many synagogues, the guests are invited to the shabbat meal where they sing and bring joy to the hatan. In some congregations, mostly Ashkenazi, it is customary that the groom and the bride cannot see each other during the week before the wedding. Therefore, the brides who hold to this custom do not come to the shabbat hatan, and instead have a shabbat kala - כלה - the bride's shabbat - at home with their friends.

\section{Divorce}

The next passage from the Talmud reveals the Judaistic stance towards divorce, "R. Eliezer said, "The altar itself weeps for him who divorces his first wife" (BT 1961, Sanhedrin 22a).

However, Judaism does provide the possibility for the divorce of marriage

24 birkat hamazon - prayer after the meal, a blessing uttered after eating the bread; it consists of four blessings. 
between a man and a woman, unlike some other religions which consider marriage to be a sacred bond that cannot be broken. This is what the Torah says, "When a man takes a wife and marries her, and it happens that she finds no favor in his eyes because he has found some indecency in her, and he writes her a certificate of divorce and puts it in her hand and sends her out from his house, and she leaves his house and goes and becomes another man's wife..." (Deut. 24:1-2). ${ }^{25}$

Divorce is allowed and possible, sometimes even imposed reality, so that in certain cases the Rabbinic court (bet din) forces the husband to divorce his wife, according to the words from the Talmud, "We force him until he agrees" (BT 1961, Kiddushin 50a). According to the Torah law, the husband has the right to divorce his wife even without her consent, but he has to have a justified reason. This was changed by the famous regulation by Rabbenu Gershom, according to which the consent for divorce must be mutual and the wife cannot be forced into divorcing.

In case that the husband's or wife's reason for divorce is not based in a real problem or a serious claim, the bet din will try and bring the couple towards reconciliation; however, if there is a serious problem, the court will initiate the divorce procedure. Acceptable reasons for divorce include: infertility, infidelity, sickness, or flaws (physical or mental) which were discovered after the wedding; a partner's rejection of sexual intercourse due to aversion or inability (impotence).

\section{Get - ג - Divorce Papers}

A Jewish couple which was married under the chuppah, according to the Law of Moses and Israel, can only be divorced by receiving the get. The divorce becomes effective when the husband puts the divorce document, called the get, into the wife's hands as it was said, “.... and he writes her a certificate of divorce and puts it in her hand and sends her out from his house" (Deut. 24:1). If a Jewish woman who is married to a Jewish man at a Jewish wedding wishes to marry another man, she must receive the get from her husband. Civil divorce is not sufficient because the bond between the partners was established according to Jewish law so it can only be dissolved and ended according to Jewish law. The woman who was not divorced with the get, but only through a civil divorce and then remarries, according to Jewish law she is still married to her first husband. This means that, apart from living a forbidden way of life, that each of her children that she bears in such a relationship will be a mamzer - ממזר (plural: mamzerim), i.e., the child of an adulterous mother. The Jews are forever forbidden from marrying a mamzer, an adulteress' offspring, which is why it is very clear just how important 
it is to get divorced according to the halacha regulations, due to the important practical consequences this brings.

The rules about the get, its form, writing, the way it is handed, and the witnesses, all are listed in detail in the Talmudic Gitin tract. One of the things that the get says is, "Behold, you are free for any man." Those who deal with divorces and who make the decision regarding the divorce must be extremely careful. The get scribe is called safra dedajane - ספרא דדינא, in Aramaic: legal notary.

The get consists of two parts: toref תורף (Aramaic: the main part), which refers to the specific couple, and it lists the reasons regarding the divorce: names of the partners, the time and place of handing the get. Tofes טופס (Aramaic: the form) is the part containing the husband's divorce statement in Aramaic. This form has been accepted at the Mishna times. The get consists of twelve lines, according to the gematric value of the word get (the letter gimel has the numerical value of 3 , while tet has 9). The get needs to be signed by two witness. Only then does it become legally effective.

The conditional get גט על תנאי is a type of get that the husband hands to the wife before going into a perilous situation such as, e.g., war. In case he goes missing in action, the get moves into effect. This get is given for two reasons. The first one is to avoid עגינות aginut (Hebr.: anchoring), because if the husband disappears, i.e., if there is never any certain evidence of his death, the wife will remain עגונה agunah (abandoned, bound) for life, i.e., she will not be legally able to marry another man. The second reason is to avoid יבום yibum and חליצה chalit$z a h$. In case where the couples do not have children and the husband dies, it is the brother-in-laws halachic obligation from the Torah ${ }^{26}$ to marry his brother's wife in order to keep his name (i.e., to conceive a son who will prolong his brother's line). This is called yibum (levirate marriage, i.e., marriage with the brother-inlaw), and the obligation of yibum would apply to a widow, but not a divorced woman. If the brother-in-law (יבם yavam) refuses to marry his brother's wife, the ritual of chalitzah is performed (Hebr.: taking off the shoe), in which the woman takes off one of the brother-in-law's shoes, spits on the floor before him and says, "Thus it is done to the man who does not build up his brother's house" (Deut. 25:9). After this, the woman receives גט חליצה the get chalitza (document of resolution by taking off of the shoe) from the Rabbinic court which absolves her from this marriage. In order to circumvent the obligations of yibuma and chalitza, the get is given ahead of time.

\section{The Condition in Israel and in the Diaspora}

In Israel, the Rabbinic courts have exclusive authority in the matters of wed- 
ding and divorce, but the secondary legal remedies, such as child-support, asset division, custody over children, determining paternity and the like, lay in the shared jurisdiction of the Rabbinic and state family courts. Such condition, when certain issues are discussed in two different judicial systems which adhere to two different legal systems, creates a problem known in Israeli legal terminology as the "race for jurisdiction." These two legal systems differ in the rights they assign to the woman and the man and in each possible element of the marital dispute there are differences in approach. In Israel, this difference creates a race between the husband and the wife: whoever gets to sue first and in which court (Rabbinic or civil), since whether they first turn to one or the other gives jurisdiction to one of them when it comes to deciding all the other matters.

In most countries of the world, the Jews in diaspora can establish a marriage through the religious wedding, which is performed by the local Rabbi. These weddings are accepted as legally valid (some states also require a civil wedding). In case of a divorce, there also needs to be a divorce paper from the Rabbinic court and the get, which need to be handed to the wife. In such cases, civil court divorce papers may not be enough and the divorce needs to be performed within the Jewish law system. If the woman who was married according to the Jewish law system never received the get (and in diaspora), she remains married to her husband and in case she has children with another man (inside a legal marriage or outside of it), they will be considered mamzerim.

\section{Violence Against Women and Judaism}

In the last section of this paper, I wish to show the attitude of Judaism towards violence against women, especially beating up and raping, and eventually the Judaistic stance on how we should treat our wives and how our wise men treated their wives.

\section{The Judaistic Stance Towards Beating Up Women}

There is no data about abusing women in Talmudic literature. The only significant reference to beating up women in the Talmud was described in a discussion about the uneducated Jewish lower classes, am ha-aretz (literally, "the people of this land"):

\footnotetext{
"It was taught that Rabbi Meir used to say, 'Whoever marries his daughter into the am ha-aretz, he might as well have tied her down and laid her in front of a lion; just like the lion rips [his prey], devours it and is not ashamed, so do the am ha-areth beat her up [hit/thrash] and lives with her with no shame" (BT Pesahim 49b; translated from Aramaic by K. D.).
} 
For centuries, the wise men of Israel expressed their deep disdain towards violent behaviour towards women, and they expressed their conviction decidedly and they were opposed to degrading the women's dignity and to beating up, especially if it was coming from the one who was supposed be the closest to her and who should be protecting her - her husband. Violent behaviour towards women is sufficient grounds for divorce (SA 1992, Even Haezer 154,3) but even more than that, it is an expression of the deep baseness of the violent man. After writing very sharply against those who dare to raise their hand against their wife, Rema ${ }^{27}$ warns that such a husband should be boycotted, expelled, and beaten up (SA 1992, Even Haezer 154,3). Rabbi Yosef Karo writes the following:

"I have seen this in a response from Rabbi Simha: He who beats his wife should be treated more severely than the man beating up his friend. This is because the wife must be respected more than one's own body (BT Yevamot 62b). He who beats his wife needs to be punished, expelled, and beaten up by the Rabbinic court (Bt Sanhedrin 58b), and if the woman wants to divorce him, he must let her divorce him." ${ }^{28}$

Many Rabbis have expressed deep consternation at such behaviour and ordered something similar in their own responsa. Some of the leading authorities included: Rashba ${ }^{29}$ from Spain in his responsa (1960. Part VII, 477), Radbaz ${ }^{30}$ from Egypt in his responsa (1972., Part III, 447), and they also describe harsh bans that

27 Ibid. The Rama, Isserles, Moses (Rabbi Moshe Iserles, short: Rema) (1520 - 1572) Son of Israel. Author of several books, most famous of which is Mappah, an addendum to Shulhan aruh by Rabbi Yosef Karo, which includes Ashkenazi customs, enabling both communities to use one book together. He wrote many responsas, he knew the Kaballah, philosophy, astronomy, history, and especially, the Torah and halacha. In his youth he was appointed judge and chairman of the Krakow yeshiva, and it was said of him, "From Moshea (Maimonides) to Moshea (Rema) there wasn't one just like Moshe (Rema).“

28 Beth Yosef in Tur, Vilnius, 1923, Even Haezer 154.; translated from Aramaic by K. D.

29 Schelomo ben Avraham Aderet, Rabbi, short: Rashba (1235 - 1310), a renowned Sephardic Rabbi. In his youth he started a trade business, but he retired from that and he became the leader of yeshiva and Rabbi in Barcelona for over 40 years. He was receiving questions from every part of the world where the Jews lived: from Spain, Portugal, France, North Africa, Germany, Turkey, Italy, and Israel, to which he wrote more than 10000 replies, which later served as the basis for the halachic book, such as Shulhan aruha. Thousands of replies have been published, but there are still thousands more that are waiting to be published. Student of Rabbenu Jonah Gerondi and Ramban. He also wrote a commentary on the Talmud and on several halachic books. His immense knowledge of Roman law, local law, and economy helped him a great deal in leading the Jewish community in Spain.

30 Rabbi David ben Solomon ibn Zimra, (1479 - 1573) also known as Radbaz, a renowned Sephardic Rabbi from $15^{\text {th }}-16^{\text {th }}$ centuries, who was also the leading authority and the dean of the yeshiva. Chief Rabbi and author of more than 3000 responsas, as well as several scientific works. 
the husband was breaking with such behaviour.

In fact, we have only mentioned the halachic references to this difficult question but we should not only look at the halacha when dealing with these evil violations, which became widespread even among us (sadly, there are several organizations in Israel who help religious women who have become victims of family violence). Severe mental destruction and the degradation of another person, who is practically helpless, does not require the halacha. It is bad enough in itself and it deserves public condemnation.

The common denominator for halachic explanations as provided by all the wise men of Israel is that they have not been given under the sponsorship of the Israeli state, and in many cases in the diaspora the legal system does not look so harshly at violence of this kind. However, there is a foundational belief in Jewish communities that the public itself can and should avoid the perpetrator and condemn such behavior. God forbid that the wife would be blamed through some falsehood! If there is a problem, it should be considered and rooted out and not covered up with lies.

If it is determined that the court does not have jurisdiction, if the repressive systems make things difficult for the person who is filing the complaint, and the social norms create a conspiracy of silence, the Torah must step up and warn about the grave injustice. This refers especially to the evening before the Rosh Hashanah and Yom Kippur, the days of judgment and forgiveness; days in which we try to cleanse our community, to cleanse ourselves and the entire nation from every bad thing.

\section{Judaistic Stance on Raping a Woman}

The Torah's stance towards raping a woman can be seen in Deuteronomy,

"But if in the field the man finds the girl who is engaged, and the man forces her and lies with her, then only the man who lies with her shall die. But you shall do nothing to the girl; there is no sin in the girl worthy of death, for just as a man rises against his neighbor and murders him, so is this case. When he found her in the field, the engaged girl cried out, but there was no one to save her" (Deut. 22:25-27).

The case that the Torah discusses is the case of an engaged girl. It is important to note that the term, engaged girl, is not what we consider it to be today (i.e., not as binding as marriage); this was basically a married woman. So, the Torah talks about raping an engaged girl (that is, she has already been consecrated to her husband, but not yet married to him), who in reality is a married woman. In this case, the Torah makes is clear that there is no basis for accusing or harming the woman (unlike some other cultures and perceptions which still exist, and which would still accuse the woman of the sexual act no less, and even more than her 
attacker). In the passage quoted above, the Torah adds another important note, which needs to be emphasized, "there is no sin in the girl worthy of death, for just as a man rises against his neighbor and murders him, so is this case" (Deut. 22:26).

The Torah decided to compare rape to nothing less than murder. From the law about the raped girl, the wise men have taught the general law about the rodef. Rodef(Hebrew, רודף, lit. "persecutor"), according to Jewish law, is the one who is "persecuting" another person in order to murder them. According to Jewish law, such a person must be killed by any observer after warning him to stop and he refuses. That is why the command was issued that the girl must be saved, even at the cost of harming the life of the one who attempted to hurt her because there is no limit to the severity of this act and its gruesomeness. It is the law in all the rodef cases: when somebody attempts to murder his neighbour, the mitzvah is to save the persecuted person, even at the cost of their persecutor's life. The Talmud teaches so,

"Our Rabbis taught: how do we know that the one who is persecuting his neighbour in order to murder him needs to be saved [from sin] at the cost of his own life? From the verse, 'you are not to act against the life of your neighbor' (Lev. 19:16.). But does that teach this? Was this not used for the next [Baraita $^{31}$ that was taught: how do we know that a man, if he sees his neighbour drowning, or hurt by a beast, or assaulted by robbers, is obligated to save him? From the verse, 'you are not to act against the life of your neighbor!' - And it's truly so. How do we know that [the persecutor] must be saved at the cost of his own life? - This conclusion was reached using the ad maius explanation regarding the engaged girl. If the Torah says of the engaged girl, whom he only wishes to disgrace, that she must be saved with the life of her kidnapper, how much more does it apply to the man who persecutes his neighbor in order to murder him. However, can the declared punishment be the result of the ad maius conclusion? - Rabbis' ${ }^{32}$ school teaches through an analogy: Just like when somebody jumps his neighbour and wants to murder him, so it is in this

31 Beraita or baraita - external; it refers to the "external" mishnas, which weren't included in the Mishna by the editors, rather they kept them in a parallel collection; see also K.D. JUDAISM, pg 515.

32 Rabbi Judah Prince (Hebr.: הודה הנשיא, Jehuda HaNasi) (135 - 217 A.D.) or Yehuda, also known as Rabbi or Rabbenu HaKadosh (Hebr.: רבנו הקדוש, "our teacher, the holy one"), was a $2^{\text {nd }}$ century Rabbi and the main redactor and editor of the Mishna. He was a key person and leader of the Jewish community at the time of the Roman occupation of Judea. According to the Talmud, he was descended from David's line, the royal line of David, which is where he got the title "nasi " - "prince." (Talmud Jerushalmi, as quoted in the Tosafot, Sanhedrin 5a.) The title, nasi, was also used to refer to the chairmans of the Sanhedrin. If it only says, Rabbi, it means Rabbi Yehuda chairman, redactor of the Mishna. 
case. ${ }^{33}$ But what are we learning from this comparison to murder ${ }^{34}$ Thus, it sheds light and is itself illuminated. ${ }^{35}$ The murderer is paralleled with an engaged girl; just like the engaged girl must be saved [from disgrace] at the price of his [assailant's] life, so in the case of murder, he [the victim] must be saved at the cost of his [assailant's] life. And how do we know this about the engaged girl? - Just like it was taught in the School of Rabbi Ishmael. Because, the School of Rabbi Ishmael taught; ' [the engaged girl cried out]; but there was no one to save her.' (Deut. 22:27) but if a saviour is here, he must save her using any means necessary [including the death of her kidnapper]." ${ }^{36}$

These words from the Talmud reflect the Torah's stance on the dignity of the woman. Women have been physically abused for generations, and when it comes to harming them, it took centuries and millennia until the full acknowledgment of women's legal and cultural rights to independence and justice. Unfortunately, however, even today we can still hear of cases where women have been treated with disrespect and abused by institutions and the public; women who have suffered sexual or other types of abuse. Sometimes the disgrace is brought by the authorities which should be enforcing the law and through the difficult burden of proving it all, the women are being hurt for the third time. Sometimes even their own community, through the conspiracy of silence, ignorance, and wickedness, oppress them and exclude them from the community. The Torah warns about this, obviously because of such unexpected actions, so that the community would know how to react to such harsh actions properly. The rapist is similar to a killer, not just because of the death penalty awaiting each of them, but also because the very act of tying up and raping a woman represents murder; inhumane behaviour and shameless disregard for the hardships and feelings of others. These words apply to the wife's husband, as well. ${ }^{37}$

\section{Respecting Women According to the Halacha}

Unlike some other religious convictions (see: Hoch-Smith 1978) which see the 
woman as being divided and extreme, Judaism views her as earthly as it sees the man. The woman's position in Judaism is esteemed and dignified and great care is taken of her soul and her nature. Judaism has more respect for women than is usually thought. The following sources from Jewish law and thought show that Judaism and Rabbinic authorities take great care of the woman's honor:

"The Rav said: May man be ever careful not to hurt a woman, because women cry easily and it's easy to hurt them" (BT 1961, Bava mecia 59a.; translated from Aramaic by K.D.).

"A woman does not wait in line before the court" (MT 1974, Sanhedrin 21,6.; translated from Aramaic by K.D.).

"Women do not stand in line for alms" (BT 1961, Yevamot 100a.; translated from Aramaic by K.D.).

"A girl-orphan has, in all things monetary (SA 1992, Jore dea 251,8 (commentary of Sifte kohen 11); see also Tosefta 1975, Ketubot 6,8.; translated from Aramaic by K.D.), advantage over the male orphan, so she wouldn't be disgraced. Rabbi Eliezer said, 'He created them male and female, and He blessed them and named them Man' (Gen 5:2)" (BT 1961, Yevamot 63a.; translated from Aramaic by K.D.).

According to the understanding of our Rabbis, man is only complete together with his wife. The respect for women in Judaism was so high, that the man was supposed to love the wife as himself, and respect her more than himself. Our scholars said in the Talmud, "The Rabbis taught that whoever loves his wife as himself, and respects her more than himself... it was said of him, 'For you will visit your abode and fear no loss' (Job 5:24)" (BT 1961, Yevamot 62b.; translated from Aramaic by K.D.).

So Maimonides passed a halacha regarding the husband's relationship to his wife: "Thus did the scholars command: man needs to respect his wife more than he respects himself, and love her as himself. If he has money, let him give her more, according to how much he has, and he must not grieve her; instead, he should talk with her pleasantly, without sadness or anger" (MT 1974, Hilhot ishut 15,19.; translated from Aramaic by K.D.).

This commandment seems to be difficult to obey; I would say it is all but impossible. How does one honor somebody else more than himself, or love them like himself? Let us look at some stories of how great Jewish men obeyed this command and how they treated their wives:

\section{“An Excellent Wife, Who Can Find?”}

King Solomon writes about the woman, "An excellent wife, who can find? For her worth is far above jewels. The heart of her husband trusts in her, and he will 
have no lack of gain. She does him good and not evil all the days of her life" (Prov. 31:10-12). King Solomon also adds, "He who finds a wife finds a good thing and obtains favor from the Lord" (Prov. 18:22).

In this wonderful chapter called, "Wise Sayings Written By King Solomon" (Prov. 31), there is a special rule for the shabbat dinner, i.e., Friday night dinner. The dinner starts with the song, Shalom aleichem - Greetings to you, serving angels... Do we sing to the angels? Yes! The Talmud (BT 1999, Shabbat 119b.) tells a story of two angels following a man home after prayer. One of them is good, the other one evil. If they find a prepared table, wine, challahs, lit candles... the good angel will wish the next Shabbat to be like this, while the evil angel replies with, "amen." If they find that the home is not prepared for Shabbat, the evil angel will wish the next Shabbat to be like this, and the good angel will have no choice but to reply with, "amen." That is why we sing to the angels, "We welcome you, come in peace, bless me in peace and leave in peace. After the Shalom aleichem, we sing Eshet hajil - An excellent wife, who can find..." (Prov. 31), a song celebrating and praising the Jewish wife. The members of her household express their gratitude and awe at the housewife for her great efforts during the week, especially during the erev shabbat.

\section{From the Lives of Our Wise Men}

I would like to finish this article with a few stories from the lives of our great Rabbis.

Rabbi Arja Levin's wife Hana had a pain in the leg one day. ${ }^{38}$ He walked her to the doctor, and upon arriving there he said completely seriously, "Doctor, my wife's leg hurts us." He loved her so much that he felt her pain.

Shragai, who was mayor of Jerusalem at the time the state was established, joined Rabbi Levin on one of his trips around town. The driver asked the Rabbi, "Where is your home?" but Rabbi Levin kept quiet and never answered. The driver asked him again, "Where would you like to leave?" The Rabbi told him the name of the street. After they exited the car, Rabbi Levin explained to Mr. Shragai, "I'm sure you were surprised I never answered the driver when he asked me about my home. You see, ever since my righteous wife died, I've had no home, because the scholars said, "His home, that's his wife" (BT 1999, Joma 2a.). So I kept quiet... but when he asked where I would like to live, I was able to name my

38 Levin, harav Arje (1885 - 1969) - Moved to Israel in 1905; he settled down in Jerusalem, where he became one of the most beloved $20^{\text {th }}$ century Rabbis due to his exquisite importance and great kindness. He was known as "the father of prisoners", because of the permanent care he provided to the members of Israeli resistance, who were captured because they fought for the land's independence at the time of the English "mandate" before the establishment of the Israeli state. 
street. $^{39}$

When Rabbi Schlomo Zalman Auerbah's ${ }^{40}$ wife died, and the funeral procession reached the grave and his students told him, "Rabbi, it is customary in Jerusalem to ask forgiveness from the deceased person." He responded, "I have never hurt my wife." Who has the audacity to repeat this statement, in these times where hurting people, including husbands and wives, is a daily and nearly inevitable occurrence? This is the revealed strength of the great Jewish men; it is not just the extent of his knowledge of the Torah, but what they are like in their private lives.

There is an excellent story in the Talmud, and it takes place at a Rabbinic college. A question was asked about how long is the husband allowed to leave his wife on her own in order to go and study the Torah in another city if he is unable to do it in his own city? This was a real situation in Talmudic times, when people would get married in the Holy Land and, after a while, they would leave for Babylon in order to study at Babylonian universities. After the destruction of the Temple, Babylon was a spiritual center for Judaism.

The Talmud tells of a $4^{\text {th }}$ generation Babylonian amorai from the beginning of the $4^{\text {th }}$ century:

"Rav Rehumi was a student of Rava in the Mahoza yeshiva (college). Each day, he would go home a day before Yom Kippur. One year he didn't come home the day before Yom Kippur, because he was preoccupied with studying. His wife waited and waited for him, telling herself that he should have already arrived, but he wasn't coming. She was very saddened and a tear trickled down her cheek. At that moment, as he was sitting, a pillar fell down on him and he died" (BT 1961, Ketubot 62b.; translated from Aramaic by K.D.).

The Talmud shows just how considerate the man has to be and to respect his wife so as not cause her any pain and, of course, without making her cry.

The man must be extra careful to respect his wife, because it is much easier to hurt a woman due to her gentle nature. The Rabbies said, "Rav said: May man

39 More about stories of Rabbi Ari Levin see at Raz, S., A Tzaddik in Our Time: The Life of Rabbi Aryeh Levin. $4^{\text {th }}$ edition. Feldheim, Jerusalem, 1989.

40 Aurbach, harav hagaon Shlomo Zalman (Jerusalem, 1910 - Jerusalem, 1995) - Son of reb Haim Yehuda Leib, founder of the Kabbalistic yeshiva Shaar Hashamajim (Heaven's Doors). He taught in the Etz Chaim (Tree Of Life) yeshiva in Jerusalem, he was later appointed head of the Kol Torah yeshiva (The Voice of Torah), and the great Rabbis from his generation were his students. He was also known as a great halachic authority in all walks of Judaism. In his halachic responsas, he deals with the relationship between halacha and technology. At 22 years of age, he published his first book, Me'ore esh, (The Fire's Light), which deals with the topic of using electricity on the shabbat. His best known responsa book is, Minhat Schelomo (Schelomo's gift), which deals with a lot of contemporary topics. 
always be careful not to hurt his wife, because it is easy to make a woman cry and it's easy to hurt them" (BT 1961, Bava mecia 59a.; see also BT 1961, Gitin 6b; see also BT 1999, Shabbat 11a.).

"Rabbi Helbo said: Man must always be careful to respect his wife, because the home is only blessed because of her, as it was said: 'Therefore he treated Abram well for her sake' (Gen. 12:16). That's why Rava said to the students in Mahoza: 'Respect your wives, so you'd be rich"' (BT 1961, Bava mecia 59a.; translated from Aramaic by K.D.).

\section{Conclusion}

Jewish tradition gives great significance and obligation to the institution of marriage. Judaism exalts and encourages the relationship between a man and a woman as a system of mutual respect and love. Rabbi Akiva made it known to everyone that the credit for his great accomplishments as Rabbi belongs to his wife, and he added that the basic assumption of Judaism - "Love your neighbour as yourself" - starts with one's own wife. As we have seen, the Talmud also considers that the man must love his wife just like he loves his own body and he must respect his wife more than he respects his own body. When compared to the situation today, it sounds completely unreal.

Maimonides writes that the man must prepare before entering his home, so that he would come home peacefully, he must not use fear to impose his authority on this family, and he must speak gently and kindly with his wife (MT 1974, Hilhot nisujin 15,19.).

The revolutionary ban on polygamy by Rabbenu Gershom and the ban of forcing the wife to accept the divorce are expressions of great respect for women.

Throughout history, the Rabbinic authorities have always considered the husband's violence over his wife to be a cruel expression of disrespect for women, and they never hesitated in imposing all kinds of punishments to such men, e.g., boycotting, and even whipping, such a man.

In conclusion, we have shown various examples from the private lives of renowned Rabbis throughout history; examples from which we learn just how important the honor of the woman was in the lives of our wise men.

\section{Bibliography}

\section{Classical Works}

Babylonian Talmud. 1961. Bnei Brak, Vilnius. Machon Tevel.

Babylonian Talmud. 1999. Jeruzalem. Steinsaltz. 
Mišne Tora (MT)- Jad Ha-Hazaka. Moshe Maimonides. 1974. (reprint of Warsaw edition from 1881). Jeruzalem.

Midraš Berešit Raba. (reprint of Vilnius edition from 1878). Jeruzalem.

Mišna with Commentary by Pinhas Kehati (1987). Jerusalem: Eliner Library, Dept. for Torah Education and Culture in the Diaspora of the World Zionist Education Tur, Vilnius, 1923. Beit Josef, Machon Yerushalim ed., Israel, 1993-1994.

Responsa Divrei Jaciv, I-VII, Rabin Yekutiel Yehuda Halberstam, Galicia and Israel (1904-1995); Israel, 1996-2001.

Responsa R. Avraham Ben Ha-Rambam. 2006. Jerusalem: R. Abraham b. HaRambam, Egypt (1186-1237). Friedberg.

Responsa Radbaz, I-VIII, R. David b. Solomon Ibn Avi Zimra, Egypt, Israel (1479-1573); Jerusalem, 1972.

Responsa Rašba, I-VII, R. Solomon b. Abraham Adret, Spain (1235-1310); Jerusalem, 1960.

Responsa Yabbia Omer, I-IX, R. Ovadija Josef, Baghdad - Israel (1920-2013); Jerusalem, 1956-1993.

Šulhan Aruh (ŠA). R. Joseph b. Ephraim Caro, Turkey, Israel (1485-1575); Karo R. Josef. 1992. Jerusalem: Ketuvim.

Tosefta. 1975. Jerusalem. Zuckermandel.

\section{Books and articles}

DaDon, Kotel. 2009. ŽIDOVSTVO: život, teologija i filozofija. Zagreb. Profil.

DaDon, Kotel. 2014. Umjetna oplodnja u židovstvu. Nova prisutnost, 12 (1): 67-90.

Hirsh, rabi Šimšon Rafael. 1989. Komentar, translation from German to Hebrew: Rabbi Mordehaj Breuer. Jerusalem: Mossad Yitzhaq Breuer.

Hoch-Smith, J., Spring, A. (ed.). 1978. Women in Ritual and Simbolic Roles. New York. Plenum.

Raz, S. 41989. A Tzaddik in Our Time: The Life of Rabbi Aryeh Levin. Jerusalem. Feldheim.

\section{Newspaper}

Jediot Aharonot, May 11, 1988.

Translated from Croatian to English by Davor Edelinski 
Kotel DaDon

\title{
Uloga žene u židovskom braku u starozavjetnim spisima Biblije, u židovskome pravu i u rabinskoj literaturi
}

\begin{abstract}
Sažetak
Članak je podijeljen u tri glavna dijela: prvi analizira ulogu žene u židovskom braku i razna pitanja koja su nerazdvojno vezana uz njezin status u judaizmu, kao što je društveni život, jednakost i poligamija. Drugi dio bavi se institucijom braka u judaizmu, samom ceremonijom sklapanja braka te raznim praktičnim pitanjima koja mogu izniknuti tijekom sklapanja braka i kasnije, primjerice ketubom i razvodom. U posljednjem dijelu ovoga članka autor nastoji prikazati stav judaizma prema nasilju nad ženama, posebno prema premlaćivanju i silovanju, te završava pogledom judaizma na to kako bismo trebali postupati sa suprugama i kako su se poznati rabini ponašali prema svojim ženama. Autor analizira navedene teme u starozavjetnim spisima Biblije, u židovskome pravu i rabinskoj literaturi od talmudskih vremena do danas. Ova pitanja autor raščlanjuje na temelju niza izvora iz rabinske literature, od talmudskih vremena preko srednjega vijeka sve do suveremenih rabina, literature koja je sada prvi put prevedena na hrvatski jezik. Tekstove je s hebrejskog i aramejskog preveo sam autor.
\end{abstract}

